\title{
Immunological events in chronic spontaneous urticaria
}

\author{
Marta Ferrer ${ }^{*}$
}

\begin{abstract}
Chronic spontaneous urticaria (CSU) is a highly debilitating skin disease associated with systemic features. We have made significant progress in several aspects relating to this condition. However, the exact physiopathology remains unknown. There is mounting evidence for an autoimmune basis, demonstrated by the CSU serum ability to activate healthy donors skin mast cells and blood basophils. However, it is only seen among 35-40\% of patients. Mast cells and basophils play an important role in this skin condition. Both cells in CSU patients have unique features that differentiate them from basophils and mast cells from healthy donors. In the case of basophils, basopenia is typically found in CSU patients. Basophils from CSU patients also tend to be hyporesponsive to stimuli that act through the lgE receptor, responsive to other stimuli as MCP-1 or C5a, and hyperesponsive when incubated with sera. Eosinophils are also present in CSU skin biopsies, yet their exact role has not yet been defined. Likewise, endothelial cells also play a function, as indirectly demonstrated by an increase of vasoactive peptides in skin and plasma of CSU patients' samples. All these facts orchestrate a systemic inflammation response producing a significant increase of several inflammatory markers. Unfortunately, we lack a unitary model that could explain the exact role of each of these players. In this review, we will describe the history and discover the pathway to the present knowledge on the immunological facts of this disease.
\end{abstract}

\section{Introduction}

Chronic spontaneous urticaria (CSU) consists of the daily appearance of pruritic wheals angioedema or both [1] for more than 6 weeks. Since the first description recorded in history in the 10th century BC in China [2], we have greatly improved our clinical approach, severity scoring, quality of life assessment, as well as tools to control the disease. However, we are still far from understanding the physiopathology of the disorder. In this review we will briefly narrate the history of the developments that have led to a potential explanation of the immunology underlying CSU.

\section{Autoimmunity}

It was in 1946 when for the first time Malmros [3] conducted for the first time his Autoserum test among 956 patients with many different types of disease, likened the wheal and flare to a histamine reaction, reporting that

\footnotetext{
*Correspondence: mferrerp@unav.edu

Department of Allergy and Clinical Immunology, Clinica Universidad de Navarra, Pio XII, 36, 31008 Pamplona, Spain
}

some patients with CSU ( 6 out of 53 positive) gave a positive autoserum test. This finding remained overlooked for another 47 years until Leznoff [4] noted a 15\% prevalence of autoimmune thyroid antibodies in patients suffering from CSU but with a normal thyroid function. Other authors have confirmed these findings $[5,6]$. This is the reason why thyroid antibody determination can be a useful tool as an indirect marker for autoimmunity.

In 1986, Grattan [7] reported that the serum from 12 patients suffering from active CSU were able to induce a positive autologous skin reaction. Subsequently, Gruber and Kaplan [8] demonstrated a non-functional IgG antiIgE by an immunoassay. Only one patient with cold urticaria showed a functional IgM anti-IgE. Later on, Grattan was the first to describe histamine releasing autoantibodies with functional properties of anti-IgE in CSU [9], this paper set the scene for the subsequent discoveries. The next big step was made when M Greaves and co-workers [10] demonstrated for the first time the functional autoantibodies in CSU. CSU sera were indeed able to activate basophils from normal donors. This ability was increased if the IgE bound to the basophils was removed 
with lactic acid and decreased when basophils were incubated with human IgE that occupies the IgE receptor. These authors also found that in $20 \%$ of patients, IgE was needed to activate the basophils. In connection with this, they deduced that they might have anti IgE antibodies. After [11] they demonstrated mast cell degranulation upon incubation with sera from a group of 163 CSU patients. Moreover, they also obtained histamine release in IgE- and non-IgE-sensitized basophils. They detected anti-FceRI $\alpha$ antibodies in $25 \%$ of CSU sera and to a lesser extent anti IgE antibodies. Notably, those sera that induced basophil histamine release did so with mast cells. Fiebiger and coworkers discovered that purified IgG from a subset (37\%) of CSU patients was able to bind to the IgE receptor. They also compared IgG from patients with atopic dermatitis and healthy donors and none of them demonstrated such an ability [12]. Furthermore [13] similar antibodies in other skin autoimmune diseases were also noted but these corresponded to IgG2 or IgG4 and were not functional, whereas in the case of CSU the antibodies corresponded to IgG1 and IgG3. Interestingly, only IgG1 and IgG3 subtypes are able to activate complement.

This hypothesis was confirmed by Kaplan [14] who transfected rat leukemia basophils with the $\alpha$ subunit of the IgE receptor and confirmed that such activation was through the interaction with the IgE receptor. An indirect observation of mast cell degranulation upon autologous serum injection [15] also confirmed that the antibodies against the $\alpha$ subunit of the FceRI receptor have the ability to induce mast cell degranulation.

Finaly, Kinet sequenced and cloned the $\alpha$ subunit of the IgE receptor and demonstrated [16] through immunoblotting that IgG from CSU sera recognized this fraction. This ability was not found in the control sera in any instance. They also were able to demonstrate that IgG and CSU sera were also able to activate mast cells with exactly the same $50 \%$ frequency as found in basophils.

Nevertheless, there is no correlation between serum reactive IgG antibodies across functional studies, Western-blot analyses and autologous skin tests [17]. The reason is still unknown. The cause is multifactorial. The high variability in basophil response to patient sera, the IgG subclass distribution and the number of $\alpha$ subunits occupied as well as conformational or glycosylation differences between the cloned and human $\alpha$ subunit are the associated factors.

In 2001 Horn [18] using intravenous immuno globulin samples, found Fc- $\varepsilon \alpha$ antibodies present in healthy donors that cross-react with tetanus toxoid. However, when Ferrer and co-workers attempted (data not published) to inhibit the binding to the $\alpha$ subunit by preincubating sera with tetanus toxoid, were not able to demonstrate such inhibition. Moreover, these data were not further confirmed. Using a tonsilar IgM library this group also found [19] antibodies against the $\alpha$ subunit of the IgE receptor that were able to induce histamine release in healthy donors. However, in order to induce such degranulation, removal of the already bound $\operatorname{IgE}$ was required. The authors hypothesized that these might represent conditional antibodies that at some point could become pathogenic because those antibodies could bind cutaneous mast cells if IgE dissociated from FceRI due to local conditions, thereby eliciting a local wheal. The existence of such antibodies has not yet been independently confirmed.

As was previously mentioned, the IgG1 or IgG3 subtypes were the subclasses identified in CSU. Utilizing purified IgG and decomplemented sera, in a study performed by Ferrer et al. were able to demonstrate that mast cell and basophil histamine release were dosedependent on C5a and were inhibited when blocked with a C5a antibody receptor [20]. The authors conclude that the release of histamine by the antibodies against the $\alpha$ subunit of the IgE receptor was increased by C5a activation [21]. The mechanism on how C5 amplifies mast cell activation, as Kaplan points out [22], takes place when two IgG molecules bind to two $\alpha$ receptors, thus activating C5a that consequently activates mast cells. The mechanism for generating C5a by immune complex formation is more likely to be by two anti-Fc\&RI IgG molecules binding adjacent FceRI on mast cells or basophils. Theoretically, it could also occur as a consequence of complexes IgG anti-IgE bound to its receptor. This would also explain why CSU patients with anti IgE receptor antibodies do not show respiratory nor systemic symptoms.

Furthermore, this ability of CSU serum to activate normal basophils was demonstrated in different ways such as by inducing CD203c [23] or CD63 [24] basophil expression upon incubation with urticaria sera. Both markers are correlated with histamine release. However, not only preformed mediators such as histamine were induced, but also non-preformed mediators as leukotrienes [24] thus indicating that such an ability activates both proximal and distal signalling pathways. Moreover, Ferrer et al. demonstrated that basophil activation also induces the production of cytokines such as IL4 [25] which explains the inflammatory milieu found in CSU biopsies.

Determinations of the HLA class 2 alleles [26] also showed an increase in the HLA DRBI*04 (corrected $\mathrm{p}=3.6 \times 10^{-6}$ ) in patients with positive serum basophil histamine releasing activity and autoreactivity or both, and a favorable association (which was statistically significant) between HLA B*50 [27] and patients with CSU, 
with an OR (95\% CI) of 2.96 (1.17-7.48) consistent with an autoimmune basis.

A very interesting review of the evidence supporting autoimmunity can be found elsewhere [28].

From an epidemiological point of view, a particularly interesting study was carried out by Confino [29] who after following-up a very large CSU population for 10 years, demonstrated a high association between the presence of autoimmune diseases and CSU.

On the basis of all these studies, it is clear that between 35 and $40 \%$ antibodies against the $\alpha$ subunit of the $\operatorname{IgE}$ receptor and between 5 and 10\% react against IgE.

Finally, an indirect evidence in favour of an autoimmune mechanism in a subset of CSU patients is the beneficial response to immunosuppressive agents and immunomodulatory treatment such as cyclosporine [30, 31], plasmapheresis [32] as well as intravenous gamma globulin [33].

Many questions remain open regarding the role of autoimmunity which is the most prominent underlying mechanism of the remaining $40-50 \%$ of patients in whom no autoimmunity is found but whose clinical features are identical.

\section{Mast cells}

Mast cells along with basophils play a key role in the pathophysiology of the disease. The first studies reported a significant increase in mast cells in CSU skin lesions $[34,35]$. However, use of specific anti-tryptase antibodies did not reproduce this finding [36]. Recently, Kay [37] reviewed this issue finding as was first reported an increase of mast cells in both affected and unaffected CSU skin.

As for mast cell functional features, one of the first studies found that [38] CSU mast cell responses to skin stimuli such as codeine were one hundred times more sensitive than normal control skin mast cells. An interesting finding reported by Jacques and co-workers [39] pointed out that the levels of histamine measured in lesional skin suction blisters correlated with disease activity. Likewise, mast cells cultured from peripheral CD34+ cells from patients with CSU showed greater spontaneous histamine release, increased Syk, and decreased SHIP-2 levels as compared with normal donors [40]. Ferrer and Schwartz [41] studied tryptase levels and found higher tryptase levels in CSU patients as compared with healthy controls and atopic donors, and also in CSU symptomatic patients at the time of the sample collection as compared with asymptomatic patients. However, when they analysed which type of tryptase was elevated, contrary to expectations, this increase was not due to mast cell degranulation and did not find a rise in mature tryptase levels.
One of the most interesting studies dealing with the connection between mast cells and autoimmunity was done by Bossi [42] who cultured two mast cell lines, one expressing IgE receptor (LAD2) and the other not expressing this receptor (HMC-1). Degranulation in both mast cell lines following incubation with CSU sera was found. Moreover, the supernatants of such cultures were able to induce vascular leakage from endothelial cells. This fact highlights the importance of endothelial cells and explains the increased expression of endothelial cell adhesion molecules [43-45]. This issue clearly needs further investigation. As Kay [43] recently reported, there is an increase in vasoactive peptides in lesional CSU skin samples. Kasperska-zajak [46] also found similar data in plasma from CSU patients.

\section{Basophils}

Although the exact role of basophils in this disease has not been demonstrated, it has been shown that peripheral blood basophils from CSU patients have unique features that reverse upon remission and in response to therapy.

A basophil abnormality is of particular interest because some patients with chronic urticaria have basopenia. This was reported as early as 1962 by Rorsman [47] and confirmed later by Grattan [48, 49] who found a correlation with urticaria severity, and was again confirmed later by Eckman [50, 51]. Interestingly, Rorsman attributed the low number of basophils to the presence of an antigen antibody reaction that leads to basophil degranulation, thus suggesting an autoimmune type of disease. The reason for such basopenia is partially explained because the presence of basophils in lesional and non-lesional skin of CSU patients and not in normal skin [52-54] has been demonstrated.

CSU basophils are different not only in number but also in function. In fact, in 1974 Greaves showed that basophils of patients with CSU were hyporesponsive to anti-IgE, and at that time attributed this feature to in vivo desensitization [55]. This quality was later confirmed by Kern and Lichtenstein [56] they reported that this feature was not observed when stimulation was applied using stimuli other than anti-IgE nor was it due to differences in histamine content. In a group of 26 patients, Sabroe correlated the basophil number, presence of autoantibodies and histamine release upon stimuli with anti-IgE and found a more marked basopenia and hypo responsiveness to anti-IgE in the autoimmune group. She postulated that this was due to basophil desensitization of the Fc\&RI pathway [57].

Ferrer compared [25] the response of basophils of healthy donors, atopic donors and CSU patients to a variety of stimuli including anti-IgE, bradykinin, MCP-1, 
$\mathrm{C} 5 \mathrm{a}$, and serum, and found that the basophils of CSU patients exhibited a diminished response to anti-IgE, and to a lesser degree to C5a. No difference was observed when basophils from CSU patients were incubated with bradykinin or MCP-1. These results are not due to a variation in histamine content since no significant differences was found between the healthy control with the urticaria basophils. Although basophils of chronic urticaria patients seem to be less responsive to stimuli such as anti-IgE or C5a which act through different receptors. The abnormality does not seem to be due to a general impairment of signaling since CSU basophils do respond normally to other stimuli that act independently from the IgE receptor such as PAF [58] in addition to bradykinin [59], and MCP-1 [60].

Surprisingly, Ferrer also observed [61] prominent histamine release when basophils of CSU patients were stimulated with other sera regardless of source. Thus, marked histamine release was obtained with sera derived from patients with chronic autoimmune and non autoimmune urticaria, or even from the normal control sera. The factor in serum that stimulates these cells has not been identified nor is the abnormal responsiveness of the cells understood. But it is clearly specific for CSU since it has never found when incubating serum with healthy normal or atopic basophil donors.

Basophils derived from patients with non autoimmune CSU were just as abnormal as basophils from patients with chronic autoimmune urticaria. Both groups of basophil were equally responsive to bradykinin, $\mathrm{C} 5 \mathrm{a}, \mathrm{MCP}-1$, or serum. Both groups were also hyporesponsive to anti IgE, thus in vivo desensitization due to the presence of autoantibody does not seem to be the explanation. The abnormality of signal transduction remains to be defined. Likewise, Lourenço [62] also found an increased surface FcદRI expression in the basophils of patients suffering from CSU and increased response to IL3. However, adding IL3 does not change those non releasers sera into releasers [63].

Interestingly, a recent paper by Saini [64] offered additional insight into this issue. The authors demonstrated the ability of active CSU serum to transfer Fc\&RI-mediated basophil histamine release suppression to healthy basophils. They did so by culturing healthy basophils with sera from patients with CSU and found a marked suppression of Fc\&RI-mediated histamine release compared with media or media with autologous serum. Again, this feature was reversed upon CSU remission. Interestingly, it was not overturned by heating serum (that would remove IgE), IgG or omalizumab.

\section{Eosinophils}

In spite of being the most abundant cells in CSU skin biopsies, little attention has been devoted to eosinophils.
One very interesting paper [65] using a peptide library found that CSU patients had IgG against CD23 present on the FceRII. This is a very attractive discovery since basophils could become activated through eosinophil major basic protein. Unfortunately, no further research has been dedicated to this hypothesis.

\section{Th1 or Th2 phenotype}

CSU is characterized by a perivascular infiltrate surrounding small venules with a predominance of $\mathrm{CD} 4+$ $\mathrm{T}$ lymphocyte cells [35] along with neutrophils, mast cell basophils, and eosinophils. There is also an increase in vascular markers both in lesional and in non lesional skin [37]. Because of level of inflammatory markers [66, 67], it is a systemic inflammatory disease not only confined to the skin.

The cellular infiltrate resembles the on which can be observed in the late phase allergic reactions. For that reason, Ferrer and co-workers questioned [25] whether the immunologic profile reflects the predominance of a Th1 or Th 2 phenotype. They initially approached this objective by determining the cytokine profile in the sera of patients with chronic urticaria. They measured INF $\gamma$ as a representative of a Th1 profile, and then measured IL4 and IL5 as representatives of a Th2 subtype. They found that IL4 was higher in the sera of patients with chronic urticaria (as well as in atopic subjects) compared to controls while IL5 and IFN $\gamma$ levels were normal. Significant differences were found in the ability of CD4+ lymphocytes to produce IL4 and INF $\gamma$ upon PMA-Ionomycin stimulus when healthy controls were compared to chronic urticaria patients. There was no difference in IL4 or INF $\gamma$ production by CD8+ lymphocytes of patients vs. the control group. Likewise, no significant differences were found when comparing the ratio of INF $\gamma / \mathrm{IL} 4$ production by CD4+ or CD8+ lymphocytes of controls and urticaria patients. The cytokine profile found in our study does not reflect either a Th1 or Th2 predominance.

These data again strengthen an immune basis for chronic urticaria, once demonstrated that the CD4+ lymphocytes of patients with this disease are activated and they release greater amounts of cytokine with a non-specific stimulus. On the other hand, this finding is similar to a study in which the cellular infiltrate associated with chronic urticaria had a Th0 profile [52]. These authors analyzed skin biopsies from chronic urticaria patients by in situ hybridization. IL4, IL5 and INFgamma revealed higher cytokine m-RNA expression in chronic urticaria patients than in healthy controls, without a predominance of either a Th1 or Th2 representative cytokine.

In a study composed by eight patients analyzed with immunohistochemistry, Kay reported a predominance 
of Th2 initiating cytokines (IL33, IL25 and TSLP) in skin lesions among patients with CSU [68]. However, it should be noted that IL33 in some instances could also promote a Th1 response [69].

\section{Coagulation pathway}

Recently Asero has reported the activation of the extrinsic coagulation pathway in patients with CSU suggesting that the coagulation cascade might be involved. It was first shown that several markers such as the prothrombin fragment F1+2 [70] and activated factor VII [71] were increased. This could be explained because in cases of severe CSU, the activation of the coagulation cascade could lead to fibrinolysis leading to an increase in D-dimer levels [72]. Interestingly, D-dimer levels correlate with the severity and could predict the lack of response to antihistamines [73]. However, increased D-dimer levelwith disease activity is not specific to CSU since it is also seen in bullous pemphigoid [74] and hereditary angioedema [75]. Thus, it is not specific for mast cell mediated disease.

Moreover, other coagulation cascade proteins are able to directly activate mast cells, as it is in the case of thrombin that cleaves protease-activated receptors [76] 1 (PAR-1) and Tissue Factor plus factor VIIa through PAR-2 [77].

The real significance of these facts in the pathogenesis of CSU is not well understood. However, they could amplify the inflammation inducing vascular permeability. Furthermore, some cascade proteins are able to induce mast cell degranulation (we include a summary of these pathways and cell cross-talk in Fig. 1).

\section{Conclusion}

Chronic spontaneous urticaria is an inflammatory disease. There is no single cell type that is uniquely responsible for CSU. Rather, there are several cells involved and each has its own unique role. So far, we have been able to describe different aspects that point in different directions but we lack a unified explanation or a chain of facts that can explain the final outcome. In this regard, several perplexing facts occur. The way corticosteroids are able to control an urticaria flare-up without being able to inhibit mast cell degranulation, or what is even more surprising, the ability of omalizumab to rapidly control the disease by means of a mechanism of action which remains elusive.

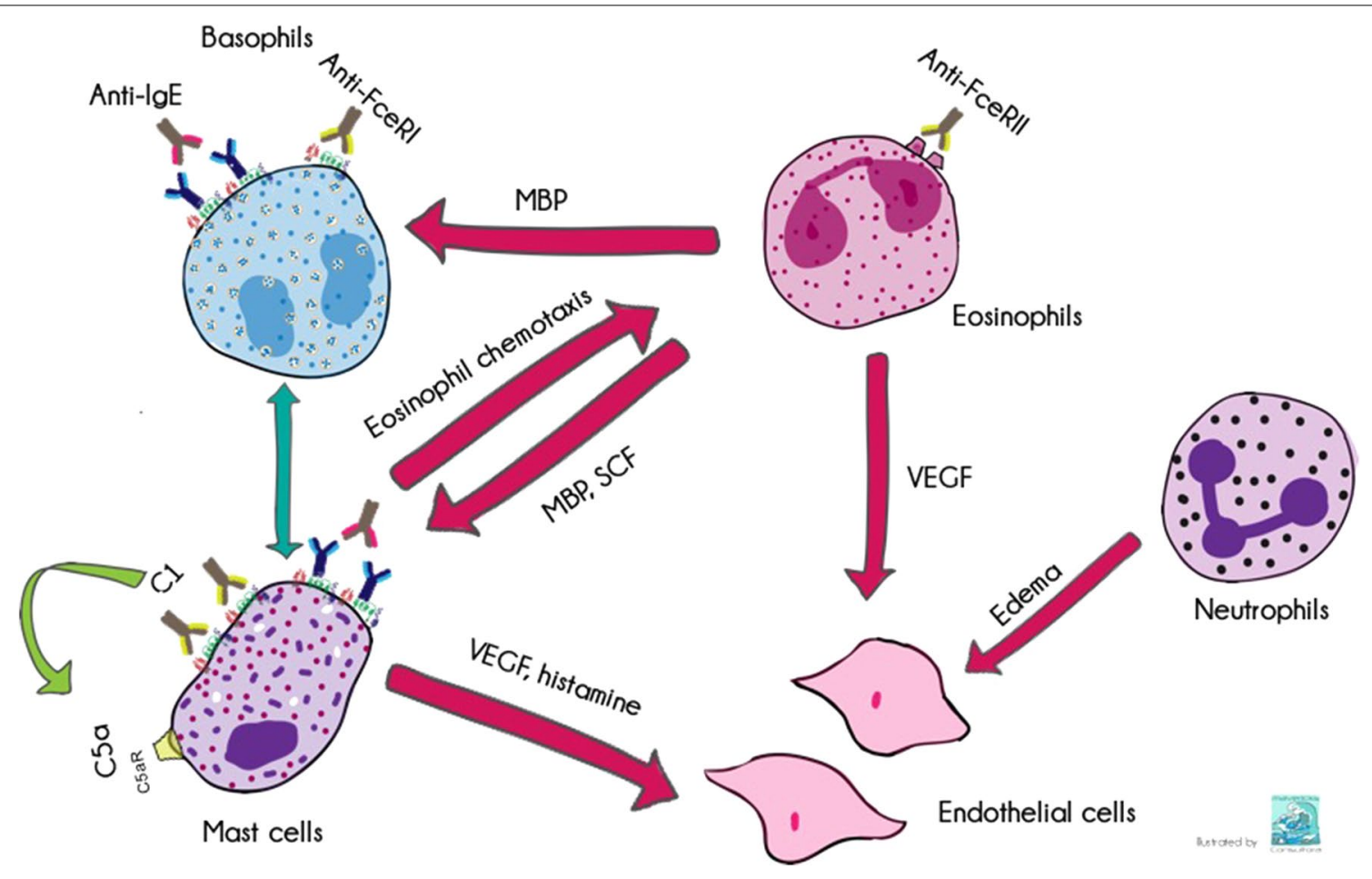

Fig. 1 We represent in a very simplistic cartoon the possible ways of activation among cells implicated in this disease. Cross-talk between mast cells and basophils remain to be defined. 


\section{Acknowledgements}

We thank Dr. Roselle Madamba for the English revision of the manuscript.

\section{Compliance with ethical guidelines}

\section{Competing interests}

Dr. Ferrer is on the scientific advisory board and a speaker for Novartis, and FAES, has served on the scientific advisory board for Genentech, receives research grant from Novartis and has received speaker honorarium from MSD, Novartis, FAES and GSK.

Received: 2 June 2015 Accepted: 29 July 2015

Published online: 25 August 2015

\section{References}

1. Zuberbier T, Aberer W, Asero R, Bindslev-Jensen C, Brzoza Z, Canonica GW et al (2014) The EAACI/GA(2) LEN/EDF/WAO Guideline for the definition, classification, diagnosis, and management of urticaria: the 2013 revision and update. Allergy 69(7):868-887. doi:10.1111/all.12313

2. Czarnetzki BM (1986) Urticaria. Springer, Berlin, Heidelberg

3. Malmros H (1946) Autoserumtest. Nordisk Med 29:150-151

4. Leznoff A, Josse RG, Denburg J, Dolovich J (1983) Association of chronic urticaria and angioedema with thyroid autoimmunity. Arch Dermatol 119(8):636-640

5. O'Donnell BF, Francis DM, Swana GT, Seed PT, Kobza Black A, Greaves MW (2005) Thyroid autoimmunity in chronic urticaria. Br J Dermatol 153(2):331-335. doi:10.1111/j.1365-2133.2005.06646.x

6. Kikuchi Y, Fann T, Kaplan AP (2003) Antithyroid antibodies in chronic urticaria and angioedema. J Allergy Clin Immunol 112(1):218

7. Grattan CE, Wallington TB, Warin RP, Kennedy CT, Bradfield JW (1986) A serological mediator in chronic idiopathic urticaria-a clinical, immunological and histological evaluation. Br J Dermatol 114(5):583-590

8. Gruber BL, Baeza ML, Marchese MJ, Agnello V, Kaplan AP (1988) Prevalence and functional role of anti-lgE autoantibodies in urticarial syndromes. J Invest Dermatol. 90(2):213-217

9. Grattan CE, Francis DM, Hide M, Greaves MW (1991) Detection of circulating histamine releasing autoantibodies with functional properties of anti-lgE in chronic urticaria. Clin Exp Allergy 21(6):695-704

10. Hide M, Francis DM, Grattan CE, Hakimi J, Kochan JP, Greaves MW (1993) Autoantibodies against the high-affinity lgE receptor as a cause of histamine release in chronic urticaria. N Engl J Med 328(22):1599-1604. doi:10.1056/NEJM199306033282204

11. Niimi N, Francis DM, Kermani F, O'Donnell BF, Hide M, Kobza-Black A et al (1996) Dermal mast cell activation by autoantibodies against the high affinity lgE receptor in chronic urticaria. J Invest Dermatol. 106(5):1001-1006

12. Fiebiger $E$, Maurer $D$, Holub H, Reininger B, Hartmann G, Woisetschlager M et al (1995) Serum lgG autoantibodies directed against the alpha chain of Fc epsilon Rl: a selective marker and pathogenetic factor for a distinct subset of chronic urticaria patients? J Clin Invest. 96(6):2606-2612

13. Fiebiger E, Hammerschmid F, Stingl G, Maurer D (1998) Anti-FcepsilonRlalpha autoantibodies in autoimmune-mediated disorders. Identification of a structure-function relationship. J Clin Invest. 101(1):243-251. doi:10.1172/JCI511

14. Tong LJ, Balakrishnan G, Kochan JP, Kinet JP, Kaplan AP (1997) Assessment of autoimmunity in patients with chronic urticaria. J Allergy Clin Immunol 99(4):461-465

15. Grattan CE, Boon AP, Eady RA, Winkelmann RK (1990) The pathology of the autologous serum skin test response in chronic urticaria resembles IgE-mediated late-phase reactions. Int Arch Allergy Appl Immunol. 93(2-3): 198-204

16. Ferrer M, Kinet JP, Kaplan AP (1998) Comparative studies of functional and binding assays for $\operatorname{lgG}$ anti-Fc(epsilon)Rlalpha (alpha-subunit) in chronic urticaria. J Allergy Clin Immunol. 101(5):672-676
17. Kikuchi Y, Kaplan AP (2001) Mechanisms of autoimmune activation of basophils in chronic urticaria. J Allergy Clin Immunol. 107(6):1056-1062

18. Horn MP, Gerster T, Ochensberger B, Derer T, Kricek F, Jouvin MH et al (1999) Human anti-FcepsilonRlalpha autoantibodies isolated from healthy donors cross-react with tetanus toxoid. Eur J Immunol 29(4):1139-1148

19. Horn MP, Pachlopnik JM, Vogel M, Dahinden M, Wurm F, Stadler BM et al (2001) Conditional autoimmunity mediated by human natural anti-Fc(epsilon)Rlalpha autoantibodies? FASEB J. 15(12):2268-2274. doi:10.1096/fj.00-0890hyp

20. Ferrer M, Nakazawa K, Kaplan AP (1999) Complement dependence of histamine release in chronic urticaria. J Allergy Clin Immunol. 104(1):169-172

21. Kikuchi Y, Kaplan AP (2002) A role for C5a in augmenting lgG-dependent histamine release from basophils in chronic urticaria. J Allergy Clin Immunol. 109(0091-6749;1):114-118

22. Kaplan AP, Greaves M (2009) Pathogenesis of chronic urticaria. Clin Exp Allergy 39(6):777-787. doi:10.1111/j.1365-2222.2009.03256.x

23. Yasnowsky KM, Dreskin SC, Efaw B, Schoen D, Vedanthan PK, Alam $R$ et al (2006) Chronic urticaria sera increase basophil CD203C expression. J Allergy Clin Immunol. 117(6):1430-1434. doi:10.1016/j. jaci.2006.02.016

24. Wedi B, Novacovic V, Koerner M, Kapp A (2000) Chronic urticaria serum induces histamine release, leukotriene production, and basophil CD63 surface expression-inhibitory effects ofanti-inflammatory drugs. J Allergy Clin Immunol 105(3):552-560

25. Ferrer M, Luquin E, Sanchez-Ibarrola A, Moreno C, Sanz ML, Kaplan AP (2002) Secretion of cytokines, histamine and leukotrienes in chronic urticaria. Int Arch Allergy Immunol 129(3):254-260. (doi:66772)

26. O'Donnell BF, O'Neill CM, Francis DM, Niimi N, Barr RM, Barlow RJ et al (1999) Human leucocyte antigen class II associations in chronic idiopathic urticaria. Br J Dermatol 140(5):853-858

27. Calamita Z, Bronhara Pela Calamita A (2013) HLA in patients with chronic spontaneous urticaria who are positive for antithyroid antibodies. J Eur Acad Dermatol Venereol 27(5):661-662. doi:10.1111/j.1468-3083.2012.04573.x

28. Konstantinou GN, Asero R, Ferrer M, Knol EF, Maurer M, Raap U et al (2013) EAACI taskforce position paper: evidence for autoimmune urticaria and proposal for defining diagnostic criteria. Allergy 68(1):27-36. doi:10.1111/ all.12056

29. Confino-Cohen R, Chodick G, Shalev V, Leshno M, Kimhi O, Goldberg A (2012) Chronic urticaria and autoimmunity: Associations found in a large population study. J Allergy Clin Immunol. 129(5):1307-1313. doi:10.1016/j.jaci.2012.01.043

30. Grattan CE, Bf OD, Francis DM, Niimi N, Barlow RJ, Seed PT et al (2000) Randomized double-blind study of cyclosporin in chronic 'idiopathic' urticaria. Br J Dermatol 143(2):365-372

31. Hollander SM, Joo SS, Wedner HJ (2011) Factors that predict the success of cyclosporine treatment for chronic urticaria. Ann Allergy Asthma Immunol 107(6):523-528. doi:10.1016/j.anai.2011.08.013

32. Grattan CE, Francis DM, Slater NG, Barlow RJ, Greaves MW (1992) Plasmapheresis for severe, unremitting, chronic urticaria. Lancet 339(8801):1078-1080

33. O'Donnell BF, Barr RM, Black AK, Francis DM, Kermani F, Niimi N et al (1998) Intravenous immunoglobulin in autoimmune chronic urticaria. Br J Dermatol 138(1):101-106

34. Haas N, Toppe E, Henz BM (1998) Microscopic morphology of different types of urticaria. Arch Dermatol 134(1):41-46

35. Natbony SF, Phillips ME, Elias JM, Godfrey HP, Kaplan AP (1983) Histologic studies of chronic idiopathic urticaria. J Allergy Clin Immunol. 71(2):177-183

36. Smith CH, Kepley C, Schwartz LB, Lee TH (1995) Mast cell number and phenotype in chronic idiopathic urticaria. J Allergy Clin Immunol. 96(3):360-364

37. Kay AB, Ying S, Ardelean E, Mlynek A, Kita H, Clark P et al (2014) Elevations in vascular markers and eosinophils in chronic spontaneous urticarial 
weals with low-level persistence in uninvolved skin. Br J Dermatol 171(3):505-511. doi:10.1111/bjd.12991

38. Cohen RW, Rosenstreich DL (1986) Discrimination between urticariaprone and other allergic patients by intradermal skin testing with codeine. J Allergy Clin Immunol. 77(6):802-807

39. Jacques P, Lavoie A, Bedard PM, Brunet C, Hebert J (1992) Chronic idiopathic urticaria: profiles of skin mast cell histamine release during active disease and remission. J Allergy Clin Immunol. 89(6):1139-1143

40. Saini SS, Paterniti M, Vasagar K, Gibbons SP Jr, Sterba PM, Vonakis BM (2009) Cultured peripheral blood mast cells from chronic idiopathic urticaria patients spontaneously degranulate upon lgE sensitization: Relationship to expression of Syk and SHIP-2. Clin Immunol. 132(3):342-348. doi:10.1016/j.clim.2009.05.003

41. Ferrer M, Nuñez-Córdoba JM, Luquin E, Grattan CE, De la Borbolla JM, Sanz ML et al (2010) Serum total tryptase levels are increased in patients with active chronic urticaria. Clin Exp Allergy 40(12):1760-1766. doi:10.1111/j.1365-2222.2010.03582.x

42. Bossi F, Frossi B, Radillo O, Cugno M, Tedeschi A, Riboldi P et al (2011) Mast cells are critically involved in serum-mediated vascular leakage in chronic urticaria beyond high-affinity lgE receptor stimulation. Allergy 66(12):1538-1545. doi:10.1111/j.1398-9995.2011.02704.x

43. Kay AB, Ying S, Ardelean E, Mlynek A, Kita H, Clark P et al (2014) Calcitonin gene-related peptide and vascular endothelial growth factor are expressed in lesional but not uninvolved skin in chronic spontaneous urticaria. Clin Exp Allergy 44(8):1053-1060. doi:10.1111/cea.12348

44. Tedeschi A, Asero R, Marzano AV, Lorini M, Fanoni D, Berti E et al (2009) Plasma levels and skin-eosinophil-expression of vascular endothelial growth factor in patients with chronic urticaria. Allergy 64(11):1616-1622. doi:10.1111/j.1398-9995.2009.02069.x

45. Lee KH, Kim JY, Kang DS, Choi YJ, Lee WJ, Ro JY (2002) Increased expression of endothelial cell adhesion molecules due to mediator release from human foreskin mast cells stimulated by autoantibodies in chronic urticaria sera. J Invest Dermatol 118(4):658-663. doi:10.1046/j.1523-1747.2002.01733.x

46. Jagodzinska J, Polaniak R, Birkner E, Kasperska-Zajac A (2015) Analysis of circulating vascular endothelial growth factor and its soluble receptors in patients with different forms of chronic urticaria. BioMed Res Int 2015:578383. doi:10.1155/2015/578383

47. Rorsman H (1962) Basophilic leucopenia in different forms of urticaria. Acta Allergol 17(0001-5148):168-184

48. Grattan CE, Walpole D, Francis DM, Niimi N, Dootson G, Edler S et al (1997) Flow cytometric analysis of basophil numbers in chronic urticaria: basopenia is related to serum histamine releasing activity. Clin Exp Allergy 27(12):1417-1424

49. Grattan CE, Walpole D, Francis DM, Niimi N, Dootson G, Edler S et al (1997) Flow cytometric analysis of basophil numbers in chronic urticaria: basopenia is related to serum histamine releasing activity. Clin Exp Allergy 27(12):1417-1424

50. Grattan CE, Dawn G, Gibbs S, Francis DM (2003) Blood basophil numbers in chronic ordinary urticaria and healthy controls: diurnal variation, influence of loratadine and prednisolone and relationship to disease activity. Clin Exp Allergy 33(3):337-341

51. Eckman JA, Hamilton RG, Gober LM, Sterba PM, Saini SS (2008) Basophil phenotypes in chronic idiopathic urticaria in relation to disease activity and autoantibodies. J Invest Dermatol. 128(8):1956-1963. doi:10.1038/ jid.2008.55

52. Ying S, Kikuchi Y, Meng Q, Kay AB, Kaplan AP (2002) TH1/TH2 cytokines and inflammatory cells in skin biopsy specimens from patients with chronic idiopathic urticaria: comparison with the allergen-induced latephase cutaneous reaction. J Allergy Clin Immunol 109(4):694-700

53. Caproni M, Volpi W, Macchia D, Giomi B, Manfredi M, Campi P et al (2003) Infiltrating cells and related cytokines in lesional skin of patients with chronic idiopathic urticaria and positive autologous serum skin test. Exp Dermatol 12(5):621-628

54. Ito Y, Satoh T, Takayama K, Miyagishi C, Walls AF, Yokozeki H (2011) Basophil recruitment and activation in inflammatory skin diseases. Allergy 66(8):1107-1113. doi:10.1111/j.1398-9995.2011.02570.x

55. Greaves MW, Plummer VM, McLaughlan P, Stanworth DR (1974) Serum and cell bound lgE in chronic urticaria. Clin Allergy 4(3):265-271
56. Kern F, Lichtenstein LM (1976) Defective histamine release in chronic urticaria. J Clin Invest 57(5):1369-1377. doi:10.1172/JCl108405

57. Sabroe RA, Francis DM, Barr RM, Black AK, Greaves MW (1998) AntiFc(episilon)RI auto antibodies and basophil histamine releasability in chronic idiopathic urticaria. J Allergy Clin Immunol 102(4 Pt 1):651-658

58. Zuberbier T, Schwarz S, Hartmann K, Pfrommer C, Czarnetzki BM (1996) Histamine releasability of basophils and skin mast cells in chronic urticaria. Allergy 51(1):24-28

59. Lawrence ID, Warner JA, Cohan VL, Lichtenstein LM, Kagey-Sobotka A, Vavrek RJ et al (1989) Induction of histamine release from human skin mast cells by bradykinin analogs. Biochem Pharmacol 38(2):227-233

60. Alam R, Lett-Brown MA, Forsythe PA, Anderson-Walters DJ, Kenamore C, Kormos C et al (1992) Monocyte chemotactic and activating factor is a potent histamine-releasing factor for basophils. J Clin Invest. 89(00219738; 3):723-728

61. Luquin E, Kaplan AP, Ferrer M (2005) Increased responsiveness of basophils of patients with chronic urticaria to sera but hyporesponsiveness to other stimuli. Clin Exp Allergy 35(4):456-460. doi:10.1111/j.1365-2222.2005.02212.x

62. Lourenço FD, Azor MH, Santos JC, Prearo E, Maruta CW, Rivitti EA et al (2008) Activated status of basophils in chronic urticaria leads to interleukin-3 hyper-responsiveness and enhancement of histamine release induced by anti-IgE stimulus. Br J Dermatol 158(5):979-986. doi:10.1111/j.1365-2133.2008.08499.x

63. Ferrer M, Luquin E, Kaplan AP (2003) IL3 effect on basophils histamine release upon stimulation with chronic urticaria sera. Allergy 58(8):802-807

64. Sterba PM, Hamilton RG, Saini SS (2015) Suppression of Basophil Fc[epsiv] RI Activation by Serum from active chronic idiopathic/spontaneous urticaria (CIU/CSU) subjects. J Invest Dermatol 135(5):1454-1456. doi:10.1038/jid.2015.13

65. Puccetti A, Bason C, Simeoni S, Millo E, Tinazzi E, Beri R et al (2005) In chronic idiopathic urticaria autoantibodies against Fc epsilonRII/CD23 induce histamine release via eosinophil activation. Clin Exp Allergy. 35(0954-7894; 12):1599-1607

66. Kasperska-Zajac A, Sztylc J, Machura E, Jop G (2011) Plasma IL-6 concentration correlates with clinical disease activity and serum C-reactive protein concentration in chronic urticaria patients. Clin Exp Allergy. doi:10.1111/j.1365-2222.2011.03789.x

67. Kasperska-Zajac A, Grzanka A, Machura E, Mazur B, Misiolek M, Czecior E et al (2013) Analysis of procalcitonin and CRP concentrations in serum of patients with chronic spontaneous urticaria. Inflamm Res Off J Eur Histamine Res Soc 62(3):309-312. doi:10.1007/s00011-012-0580-1

68. Kay AB, Clark P, Maurer M, Ying S (2014) Elevations in T-helper-2-initiating cytokines (interleukin-33, interleukin-25 and thymic stromal lymphopoietin) in lesional skin from chronic spontaneous ('idiopathic') urticaria. Br J Dermatol. doi:10.1111/bjd.13621

69. Sattler S, Ling GS, Xu D, Hussaarts L, Romaine A, Zhao H et al (2014) IL10-producing regulatory $B$ cells induced by IL-33 (Breg(IL-33)) effectively attenuate mucosal inflammatory responses in the gut. J Autoimmun 50:107-122. doi:10.1016/j.jaut.2014.01.032

70. Asero R, Tedeschi A, Riboldi P, Cugno M (2006) Plasma of patients with chronic urticaria shows signs of thrombin generation, and its intradermal injection causes wheal-and-flare reactions much more frequently than autologous serum. J Allergy Clin Immunol. 117(5):1113-1117. doi:10.1016/j.jaci.2005.12.1343

71. Asero R, Tedeschi A, Coppola R, Griffini S, Paparella P, Riboldi P et al (2007) Activation of the tissue factor pathway of blood coagulation in patients with chronic urticaria. J Allergy Clin Immunol. 119(3):705-710. doi:10.1016/j.jaci.2006.08.043

72. Asero R, Tedeschi A, Riboldi P, Griffini S, Bonanni E, Cugno M (2008) Severe chronic urticaria is associated with elevated plasma levels of D-dimer. Allergy 63(2):176-180. doi:10.1111/j.1398-9995.2007.01514.x

73. Asero R (2013) D-dimer: a biomarker for antihistamine-resistant chronic urticaria. J Allergy Clin Immunol 132(4):983-986. doi:10.1016/j. jaci.2013.04.037

74. Marzano AV, Tedeschi A, Fanoni D, Bonanni E, Venegoni L, Berti E et al (2009) Activation of blood coagulation in bullous pemphigoid: role of eosinophils, and local and systemic implications. Br J Dermatol 160(2):266-272. doi:10.1111/j.1365-2133.2008.08880.x 
75. Cugno M, Zanichelli A, Bellatorre AG, Griffini S, Cicardi M (2009) Plasma biomarkers of acute attacks in patients with angioedema due to C1-inhibitor deficiency. Allergy 64(2):254-257. doi:10.1111/j.1398-9995.2008.01859.x

76. Ossovskaya VS, Bunnett NW (2004) Protease-activated receptors: contribution to physiology and disease. Physiol Rev 84(2):579-621. doi:10.1152 physrev.00028.2003
77. Rattenholl A, Steinhoff M (2008) Proteinase-activated receptor-2 in the skin: receptor expression, activation and function during health and disease. Drug News Perspect 21(7):369-381. doi:10.1358/ dnp.2008.21.7.1255294

Submit your next manuscript to BioMed Central and take full advantage of:

- Convenient online submission

- Thorough peer review

- No space constraints or color figure charges

- Immediate publication on acceptance

- Inclusion in PubMed, CAS, Scopus and Google Scholar

- Research which is freely available for redistribution

Submit your manuscript at

www.biomedcentral.com/submit

() BioMed Central 